\title{
Penerapan Model Pembelajaran Group Investigation Sebagai Upaya Meningkatkan Hasil Belajar Siswa Dalam Pembelajaran Agama Islam di Kelas IV SDN 064969 Kecamatan Medan Tembung Pada Semester 1 TP.2019/2020
}

\author{
Sri Wahyuningsih
}

Title : S.Pd.I , NIP : 196505221986042002

Guru Pendidikan Agama Islam di SDN 064969 Kecamatan Medan Tembung

sriwahyun005@gmail.com

\begin{abstract}
ABSTRAK
Sri Wahyuningsih,S.Pd.I,NIP:19650522 1986042 002,Guru Pendidikan Agama Islam di SDN 064969 Kecamatan Medan Tembung:"Penerapan Model Pembelajaran Group Investigation Sebagai Upaya Meningkatkan Hasil Belajar Siswa Dalam Pembelajaran Agama Islam Di Kelas IV SDN 064969 Kecamatan Medan Tembung Pada Semester 1 T.P.2019/2020". Penelitian ini bertujuan untuk: Meningkatkan hasil belajar siswa dalam pembelajaran Pembelajaran Agama Islam Di Kelas IV SDN 064969 Kecamatan Medan Tembung dengan model pembelajaran Group Investigation. Dengan Penelitian Tindakan Kelas ini, diharapkan terjadi perbaikan dan peningkatan hasil pembelajaran sebagai berikut : 1.Bagi siswa ; mereka lebih tertarik mempelajari Agama Islam. 2. Bagi guru ; dapat memacu kreativitas dalam menemukan berbagai metode dan model pembelajaran yang lebih efektif. 3. Bagi sekolah ; dapat mempengaruhi peningkatan kualitas pembelajaran di sekolah ini. Prosedur penelitian tindakan kelas dilaksanakan dalam 2 (dua) siklus dengan 4 (empat) tahapan yaitu: 1).Planning/ Perencanaan; 2).Acting/ Tindakan; 3).Observing/ Pengamatan; 4).Reflekting/ Refleksi. Hal-hal yang belum memuaskan akan direfleksikan sebagai bahan perbaikan pengajaran pada siklus berikutnya. Hasil penelitian: 1. Penerapan Metode Group Investigation menunjukkan peningkatan hasil belajar siswa dalam Pembelajaran Agama Islam Di Kelas IV SDN 064969 Kecamatan Medan Tembung hal ini terbukti dalam penelitian ini bahwa pada siklus II 86,67\% dari siswa yang menjadi subjek penelitian tuntas belajar dengan nilai rata-rata 74,67. 2. Penerapan Metode Group Investigation menunjukkan peningkatan aktivitas belajar siswa dalam Pembelajaran Agamas Islam Di Kelas IV SDN 064969 Kecamatan Medan Tembung hal ini terbukti dalam penelitian ini bahwa siswa aktif belajar dalam kelompok, hal ini terbukti dari peningkatan hasil belajar kelompok dari rata-rata nilai 57 pada siklus I menjadi 87 pada siklus II.
\end{abstract}

Kata Kunci : Model Pembelajaran, Group Investigation, Hasil Belajar

\begin{abstract}
Sri Wahyuningsih, S.Pd.I, NIP: 196505221986042 002, Teacher of Islamic Education at SDN 064969 Medan Tembung District: "Application of Group Investigation Learning Model as an Effort to Improve Student Learning Outcomes in Learning Islam in Class IV SDN 064969 Medan District Bloating in Semester 1 TP2019/2020 ". This study aims to: Improve student learning outcomes in learning Islamic Religion in Class IV SDN 064969 Medan Tembung Subdistrict with the Group Investigation learning model. With this Classroom Action Research, it is expected that there will be improvements and improvements in learning outcomes as follows: 1. For students; they are more interested in studying Islam. 2. For teachers; can spur creativity in finding various methods and learning models that are more effective. 3. For schools; can affect the improvement of the quality of learning in this school. Classroom action research procedures are carried out in 2 (two) cycles with 4 (four) stages, namely: 1) Planning / Planning; 2) .Acting / Action; 3) .Observing / Observation; 4) Reflection / Reflection. Things that are not satisfactory will be reflected as teaching improvement materials in the next cycle. The results of the study: 1. The application of the Group Investigation method shows an increase in student learning outcomes in Islamic Religion Learning in Class IV SDN 064969 Medan Tembung District. an average of 74.67. 2. The application of the Group Investigation method shows an increase in student learning activities in Islamic Religion Learning in Class IV SDN 064969 Medan Tembung District. in cycle I to 87 in cycle II.
\end{abstract}

Keywords : Learning Models, Group Investigation, Learning Outcomes 
Wahyuningsih S : Penerapan Model Pembelajaran Group Investigation Sebagai Upaya Meningkatkan Hasil Belajar Siswa Dalam Pembelajaran Agama Islam di Kelas IV SDN 064969 Kecamatan Medan Tembung Pada Semester 1 TP.2019/2020

\section{PENDAHULUAN}

\section{Latar Belakang}

Guru memiliki peranan yang sangat penting dalam menentukan kuantitas dan kualitas pengajaran yang dilaksanakan. Oleh sebab itu, guru harus memikirkan dan membuat perencanaan secara seksama dalam meningkatkan kesempatan belajar bagi siswanya dan memperbaiki kualitas mengajarnya. Hal ini menuntut perubahan-perubahan dalam mengorganisasikan kelas, penggunaan metode mengajar, strategi belajar mengajar, maupun sikap dan karakteristik guru dalam mengelola proses belajar mengajar. Guru berperan sebagai pengelola proses belajar-mengajar, bertindak sebagai fasilitor yang berusaha mencipatakan kondisi belajar mengajar yang efektif, sehingga memungkinkan proses belajar mengajar, mengembangkan bahan pelajaran dengan baik, dan meningkatkan kemampuan siswa untuk menyimak pelajaran dan menguasai tujuan-tujuan pendidikan yang harus mereka capai. Untuk memenuhi hal tersebut di atas, guru dituntut mampu mengelola proses belajar mengajar yang memberikan rangsangan kepada siswa, sehingga ia mau belajar karena siswalah subyek utama dalam belajar. Pembelajaran Group Investigation lebih menekankan interaksi antar siswa. Dari sini siswa akan melakukan komunikasi aktif dengan sesama temannya. Dengan komunikasi tersebut diharapkan siswa dapat menguasai materi pelajaran dengan mudah karena "siswa lebih mudah memahami penjelasan dari kawannya dibanding penjelasan dari guru, karena taraf pengetahuan serta pemikiran mereka lebih sejalan dan sepadan. Pembelajaran Agama Islam tidak lagi mengutamakan pada penyerapan melalui pencapaian informasi, tetapi lebih mengutamakan pada pengembangan kemampuan dan karakter. Untuk itu aktivitas peserta didik perlu ditingkatkan melalui latihan-latihan atau tugas dengan bekerja dalam kelompok kecil dan menjelaskan ide-ide kepada orang lain. Namun dalam kenyataannya, guru seringkali mengabaikan proses pembinaan tatanan nilai, sikap dan tindakan, sehingga mata pelajaran Agama Islam dianggap sebagai mata pelajaran yang lebih cenderung menjadi mata pelajaran yang jenuh dan membosankan.

\section{Perumusan Masalah}

Perumusan Masalah pada penelitian kali ini adalah sebagai berikut :

1. Bagaimana model pembelajaran Group Investigation dapat meningkatkan hasil belajar siswa dalam pembelajaran Pembelajaran Agama Islam Di Kelas IV SDN 064969 Kecamatan Medan Tembung Pada Semester 1 T.P.2019/2020 ?

2. Apakah guru mampu menerapkan model pembelajaran Group Investigation pada pembelajaran Pembelajaran Agama Islam Di Kelas IV SDN 064969 Kecamatan Medan Tembung Pada Semester 1 T.P.2019/2020?

\section{Tujuan Penelitian}

Penelitian ini bertujuan yaitu :

Meningkatkan hasil belajar siswa dalam pembelajaran Pembelajaran Agama Islam Di Kelas IV SDN 064969 Kecamatan Medan Tembung Pada Semester 1 T.P.2019/2020 melalui penerapan model pembelajaran Group Investigation.

\section{Manfaat Penelitian}

Dengan Penelitian Tindakan Kelas ini, diharapkan terjadi perbaikan dan peningkatan hasil pembelajaran sebagai berikut :

1. Bagi siswa ; mereka lebih tertarik mempelajari Agama Islam.

2. Bagi guru ; dapat memacu kreativitas dalam menemukan berbagai metode dan model pembelajaran yang lebih efektif.

3. Bagi sekolah; dapat mempengaruhi peningkatan kualitas pembelajaran di sekolah ini. 
Wahyuningsih S : Penerapan Model Pembelajaran Group Investigation Sebagai Upaya Meningkatkan Hasil Belajar Siswa Dalam Pembelajaran Agama Islam di Kelas IV SDN 064969 Kecamatan Medan Tembung Pada Semester 1 TP.2019/2020

\section{METODE PENELITIAN}

\section{Tempat dan Waktu Penelitian}

Penelitian ini dilakukan di SDN 064969. Alasan peneliti memilih lokasi ini karena peneliti bertugas sebagai Guru Agama Islam di Sekolah tersebut. Penelitian dilakukan selama tiga bulan pada Semester 1 TP.2019/2020, dimulai dari bulan Juli sampai dengan September 2019.

\section{Populasi dan Sampel serta Objek Penelitian}

Yang menjadi Subjek dalam penelitian ini adalah Populasi seluruh siswa di kelas IV SDN 064969 Kecamatan Medan Tembung Pada Semester 1 TP.2019/2020 dengan jumlah sebanyak 30 orang yang terdiri dari siswa heterogen. Sampel yang digunakan adalah total keseluruhan dari 30 orang tersebut. Sementara Objek penelitian adalah Model Pembelajaran Group Investigation, dimana hasil belajar siswa dan tanggapan siswa terhadap pembelajaran yang dilakukan.

\section{Teknik Pengumpulan Data}

Sumber data adalah Siswa kelas IV SDN 064969 Kecamatan Medan Tembung dan guruguru disekolah tersebut. Teknik pengumpulan data : Observasi, Evaluasi, dan Dokumentasi. Untuk memperoleh data yang diperlukan secara efektif dan efisien, pengumpulan data dilakukan melalui: Instrumen Observasi digunakan dalam pengamatan langsung di dalam kelas oleh pengamat yang sudah ditentukan, dengan fokus observasi terhadap aktivitas siswa dan guru selama proses pembelajaran dengan Model Pembelajaran Group Investigation. Evaluasi atau Tes dilakukan untuk mengukur hasil belajar siswa. Dokumentasi Menggunakan kamera untuk mengambil foto pada kegiatan proses pembelajaran.

\section{Prosedur Penelitian}

Penelitian ini dilakukan dengan menggunakan Metode Tindakan Kelas yang terdiri dari 2 siklus. Langkah-langkah pada setiap siklus adalah sebagai berikut :

\section{Perencanaan}

Menentukan SK, KD, dan Bahan ajar, menyusun scenario berdasarkan model GI dan menyusun instrument penelitian berupa lembar observasi dan perangkat tes

\section{Tindakan}

Melaksanakan praktek mengajar dengan langkah-langkah yaitu : Siklus Pertama Kegiatan awal (s1) - Kegiatan Inti (s1) - Kegiatan Penutup (s1), kemudian pada siklus kedua atau pertemuan kedua Kegiatan awal (s2) - Kegiatan Inti (s2) - Kegiatan Penutup (s2).

\section{Analisis Data}

Analisis data dilakukan secara deskriptif komparatif yaitu membandingkan data antar siklus atau dengan indikator kinerja. Setelah data penelitian dikumpulkan, data tersebut diolah dengan langkah-langkah sebagai berikut:

1. Tahap mentabulasi data, semua data yang diperoleh ditabulasikan.

2. Tahap pengolahan data, semua data yang terkumpul diklasifikasikan, dianalisis kemudian disimpulkan.

Kualifikasi data ditetapkan sebagai berikut:

$0-39,9=$ Sangat kurang;

$40,0-54,9=$ Kurang;

$55,0-69,9=$ Cukup;

$70,0-84,8=$ Baik; dan 
Wahyuningsih S : Penerapan Model Pembelajaran Group Investigation Sebagai Upaya Meningkatkan Hasil Belajar Siswa Dalam Pembelajaran Agama Islam di Kelas IV SDN 064969 Kecamatan Medan Tembung Pada Semester 1 TP.2019/2020

$85,0-100=$ Sangat baik .

Dengan KKM (Kriteria Ketuntasan Minimal $)=70$ dan memenuhi 85\% atau lebih siswa yang memenuhi nilai KKM.

3. Tahap penulisan laporan.

\section{Pengamatan/Evaluasi , Analisis dan Refleksi}

Pengamatan dilakukan terhadap aktivitas siswa dan guru selama proses pembelajaran dilakukan oleh observer. Sebelum penelitian dilakukan, peneliti mengadakan diskusi dengan pengamat tentang teknis pelaksanaan pengamatan. Diskusi juga dilakukan setelah pengamatan selesai untuk mengetahui kelebihan-kelebihan dan kekurangan-kekurangan proses pembelajaran yang sudah berlangsung. Pada akhir pembelajaran peneliti melakukan evaluasi dengan menggunakan tes. Data yang terkumpul dianalisa secara deskriptif komparatif yaitu membandingkan data antar siklus atau dengan indikator kinerja. Berdasarkan analisis data yang diperoleh melalui observasi dan evaluasi dapat diketahui tingkat ketercapaian tindakan yang telah dilakukan baik yang terkait dengan proses maupun terhadap hasil tindakan. Berdasarkan analisis data tersebut dapat diketahui aspek yang merupakan kekuatan-kekuatan dan kelemahan-kelemahan atau hambatan-hambatan yang mengganjal upaya dalam pencapaian tujuan secara optimal dan respon siswa. Aspek kelemahan tersebut diperbaiki pada tindakan berikutnya.

\section{HASIL PENELITIAN}

\section{Hasil dan Pembahasan Siklus I}

\section{Aktivitas Siswa}

Hasil pengamatan yang dilakukan oleh observer pada siklus I terhadap aktivitas siswa dalam kelompok pada kegiatan pembelajaran dengan metode Group Investigation disajikan pada tabel berikut.

Tabel 1. Aktivitas Siswa Dalam Kelompok Pada Siklus I

\begin{tabular}{|l|l|l|l|}
\hline \multirow{2}{*}{ No } & Katagori Pengamatan & \multicolumn{2}{l|}{ Siklus I } \\
\cline { 3 - 4 } & & Jumlah & \% \\
\hline 1 & Jumlah siswa yang terlibat aktif dalam kelompok 1 - 2 orang. & 10 & 8,33 \\
\hline 2 & Jumlah siswa yang terlibat aktif dalam kelompok 3 - 4 orang. & 19 & 15,83 \\
\hline 3 & Jumlah siswa yang terlibat aktif dalam 5 - 6 orang. & 13 & 10,83 \\
\hline 4 & Ada pembagian tugas anggota kelompok & 17 & 14,16 \\
\hline 5 & Tidak ada pembagian tugas anggota dalam kelompok & 11 & 9,16 \\
\hline 6 & Tugas dilaksanakan sesuai dengan prosedur. & 21 & 17,15 \\
\hline 7 & Tugas dilaksanakan tidak sesuai dengan langkah - langkah. & 11 & 9,16 \\
\hline 8 & $\begin{array}{l}\text { Terdapat perilaku anggota kelompok yg tdk relevan dengan } \\
\text { KBM. }\end{array}$ & 18 & 15 \\
\hline
\end{tabular}

Keterangan : Jumlah $=$ jumlah total aktivitas dalam 1 siklus

$\%=$ persentase aktivitas

Mencermati tabel 1 aktivitas siswa dalam kelompok dengan tindakan menggunakan metode Group Investigation dipaparkan pada uraian hasil penelitian berikut : Pada siklus I, aktivitas 1, 2, dan 3 (jumlah siswa yang terlibat dalam kelompok) menunjukkan adanya perbedaan keterlibatan. Siswa yang terlibat aktif dalam kelompok lebih di dominasi 3 sampai 4 orang saja, sebesar $15,83 \%$. Sedangkan secara keseluruhan siswa yang terlibat aktif yaitu 5 sampai 6 orang hanya 10,83\%. Hal ini mengindikasikan bahwa siswa belum dapat menempatkan dirinya dalam kelompok untuk bekerja sama menyelesaikan tugas yang diberikan guru. 
Wahyuningsih S : Penerapan Model Pembelajaran Group Investigation Sebagai Upaya Meningkatkan Hasil Belajar Siswa Dalam Pembelajaran Agama Islam di Kelas IV SDN 064969 Kecamatan Medan Tembung Pada Semester 1 TP.2019/2020

Sehingga hanya beberapa orang saja yang terlibat secara aktif dalam penyelesaian tugas kelompok. Pada aktivitas 4 dan 5 yaitu mengenai pembagian tugas anggota kelompok, menunjukkan 14,16\% kelompok memberikan tugas kepada anggota-anggotanya. Sedangkan sekitar 9,16\% saja yang tidak ada pembagian tugas anggota dalam kelompok. Hal ini mengindikasikan bahwa siswa sudah memiliki rasa tanggung jawab terhadap tugas yang diberikan, dimana mereka langsung mengambil peran dalam kelompoknya dengan membagi tugas sehingga pekerjaan kelompok dapat selesai sebagaimana mestinya. Kondisi kerjasama yang dilakukan juga tercermin oleh aktivitas ke 6 dan 7 yaitu mengenai prosedur kerja yang dilakukan. Sebanyak 17,5 \% kelompok melaksanakan tugas sesuai dengan langkah-langkah yang telah ditetapkan oleh guru, dibandingkan dengan yang belum melaksanakan sesuai langkah-langkah yaitu sekitar 9,16\%.

\section{Aktivitas Guru}

Selanjutnya mengenai hasil pengamatan aktivitas guru pada siklus I ini ditunjukkan pada tabel berikut :

Tabel 2 Aktivitas Guru Pada Siklus I

\begin{tabular}{|l|l|l|l|}
\hline & Katagori Pengamatan & \multicolumn{2}{|l|}{ Siklus I } \\
\cline { 3 - 4 } No & & Jumlah & $\%$ \\
\hline 1 & Menyampaikan Pendahuluan.. & 8 & 10 \\
\hline 2 & Menjelaskan materi / demonstrasi keterampilan. & 6 & 7,5 \\
\hline 3 & Membagi kelompok siswa & 10 & 12,5 \\
\hline 4 & Membagikan tugas kepada kelompok & 1,5 & 1,88 \\
\hline 5 & Meminta siswa untuk mempersiapkan peralatan & 2 & 2,5 \\
\hline 6 & Memberikan instruksi dan motivasi & 2 & 2,5 \\
\hline 7 & Mengamati kegiatan siswa dalam kelompok & 24 & 30 \\
\hline 8 & Memberikan umpan balik terhadap keluhan siswa. & 6 & 7,5 \\
\hline 9 & Memberikan evaluasi singkat terhadap hasil kerja kelompok. & 5,5 & 6,88 \\
\hline 10 & Menutup pelajaran. & 15 & 18,8 \\
\hline 11 & Perilaku yang tidak relevan & 0 & 0 \\
\hline
\end{tabular}

Keterangan : Jumlah $=$ jumlah total aktivitas dalam 1 siklus

$$
\%=\text { persentase aktivitas }
$$

Pada siklus I ini aktivitas yang dilakukan guru telah sesuai dengan rencana pembelajaran yang dibuat, dimana semua aktivitas pembelajaran telah dilakukan. Dari hasil pengamatan yang dilakukan oleh observer diperoleh hasil sebagaimana yang tertera pada tabel 4.2 di atas, bahwa aktivitas guru dalam menyampaikan pendahuluan menunjukkan jumlah pengamatan observer adalah 8 menit dengan persentase sebesar $10 \%$. Hal ini mengindikasikan bahwa guru telah melakukan kegiatan pendahuluan sesuai dengan waktu yang ditentukan. Pada aktivitas ke-2 yaitu menjelaskan materi, guru melakukannya dengan waktu 6 menit atau 7,5 $\%$. Membagi kelompok membutuhkan waktu 10 menit atau 12,5\%, membagikan tugas menyita waktu 1,5 menit atau 1,88\%, meminta siswa untuk mempersiapkan alat tulis dan memberikan instruksi menyita waktu 2 menit atau 2,5\%. Untuk aktivitas ke-7 yaitu mengamati kegiatan siswa dalam kelompok menggunakan waktu 24 menit atau $30 \%$, memberikan umpan balik terhadap keluhan siswa membutuhkan waktu 6 menit atau 7,5 \%. Selanjutnya mengenai aktivitas ke-9 mengenai kegiatan evaluasi yang diberikan guru terhadap hasil kerja kelompok siswa membutuhkan waktu 5,6 menit atau 6,88\%. Dari pemaparan hasil pengamatan untuk aktivitas ke-2 sampai ke-9 seluruhnya membutuhkan waktu selam 65 menit. Sedangkan waktu yang dialokasikan sesuai dengan RPP hanya 
Wahyuningsih S : Penerapan Model Pembelajaran Group Investigation Sebagai Upaya Meningkatkan Hasil Belajar Siswa Dalam Pembelajaran Agama Islam di Kelas IV SDN 064969 Kecamatan Medan Tembung Pada Semester 1 TP.2019/2020

selama 60 menit. Hal ini mengindikasikan bahwa guru dalam melakukan kegiatan inti telah melebihi waktu selama 5 menit dari waktu yang ditentukan. Pada aktivitas ke-10 yaitu kegiatan menutup pelajaran, guru menggunakan waktu selama 15 menit atau 18,8\%, lebih singkat 1,2 menit dari waktu yang ditetapkan yaitu selama 20 menit. Hal ini terjadi karena waktunya terpakai pada kegiatan inti pembelajaran seperti yang telah diungkapkan di atas.

\section{Penilaian Proses dan Hasil Kerja}

Penilaian proses dilakukan dengan 4 indikator yaitu: Kerjasama, Kesungguhan, Keberanian dan Perhatian. Masing-masing indikator memiliki rentang skor 1 sampai 5. Sehingga total skor adalah 20. Untuk memperoleh nilai maka jumlah skor yang diperoleh dikalikan dengan 5. Sehingga nilai maksimum adalah 100 . Hasil perolehan nilai untuk masing-masing kelompok diuraikan pada tabel sebagai berikut :

Tabel 3 Perolehan Nilai Per-Kelompok Siklus I

\begin{tabular}{|l|l|l|l|l|l|l|l|}
\hline \multirow{2}{*}{ No } & \multirow{2}{*}{ Nama Kelompok } & \multicolumn{2}{|l|}{ Indikator Penilaian } & \multirow{2}{*}{ Skor } & Nilai \\
\cline { 2 - 8 } & $\mathbf{1}$ & $\mathbf{2}$ & $\mathbf{3}$ & $\mathbf{4}$ & 9 & 45 \\
\hline 1. & I & 2 & 1 & 3 & 3 & 9 & 65 \\
\hline 2. & II & 3 & 2 & 4 & 4 & 13 & 65 \\
\hline 3. & III & 3 & 4 & 3 & 3 & 13 & 40 \\
\hline 4. & IV & 2 & 1 & 3 & 2 & 8 & 70 \\
\hline 5. & V & 4 & 4 & 3 & 3 & 14 & \\
\hline
\end{tabular}

Rumus : Nilai $=$ Jumlah Skor perolehan x 5

\section{Refleksi Siklus I}

Analisis terhadap hasil pengamatan, catatan lapangan, dijadikan bahan untuk menentukan tindakan selanjutnya, terutama yang berkaitan dengan masih rendahnya perolehan nilai hasil belajar yang mereka peroleh. Tindakan refleksi ditunjukkan pada aktivitas guru dan siswa yang dilakukan selama siklus I. Setelah melakukan kolaborasi antara observer dengan peneliti, maka diperoleh hasil refleksi sebagai berikut:

1. Aspek keberhasilan

- Sebagian besar siswa menyatakan bahwa metode Group Investigation sangat menarik sehingga mendorong mereka untuk aktif belajar.

- Pembelajaran dengan menggunakan metode Group Investigation lebih memudahkan mereka mengerti tentang materi pelajaran, walaupun masih belum baik hasilnya.

- Sebagian besar siswa telah mengetahui langkah-langkah atau prosedur belajar dengan metode Group Investigation.

- Aktivitas guru dalam pembelajaran sudah sesuai dengan rencana yang ditetapkan sebelumnya.

- Waktu yang digunakan guru sudah efektif artinya sesuai dengan rencana awal yang tertera di RPP.

2. Aspek kelemahan

- Keterlibatan siswa dalam kelompok masih rendah.

- Hasil kerja kelompok masih belum sempurna.

- Pembagian tugas anggota kelompok belum merata dilakukan sehingga masih ditemukannya perilaku yang tidak relevan dengan aktivitas pembelajaran. 
Wahyuningsih S : Penerapan Model Pembelajaran Group Investigation Sebagai Upaya Meningkatkan Hasil Belajar Siswa Dalam Pembelajaran Agama Islam di Kelas IV SDN 064969 Kecamatan Medan Tembung Pada Semester 1 TP.2019/2020

- Guru perlu lebih optimal lagi untuk memotivasi dan membimbing siswa agar mampu bekerja sama dalam satu kelompok.

Dengan demikian hasil belajar pada siklus I dengan penerapan model pembelajaran Group Investigation masih memerlukan perbaikan. Untuk memperbaiki kondisi ini peneliti melakukan tindakan pada siklus II.

\section{Siklus II}

\section{Aktivitas Siswa}

Hasil observasi yang dilakukan oleh observer pada siklus II terhadap aktivitas siswa dalam kelompok pada kegiatan pembelajaran dengan menggunakan metode Group Investigation disajikan pada tabel berikut:

\section{Tabel 4 Aktivitas Siswa Dalam Kelompok Pada Siklus II}

\begin{tabular}{|l|l|l|l|}
\hline No & Katagori Pengamatan & Siklus I \\
\cline { 3 - 4 } & \multicolumn{1}{|l|}{ Jumlah } & \% \\
\hline 1 & $\begin{array}{l}\text { Jumlah siswa yang terlibat aktif dalam kelompok 1 - 2 } \\
\text { orang. }\end{array}$ & 6 & 5 \\
\hline 2 & $\begin{array}{l}\text { Jumlah siswa yang terlibat aktif dalam kelompok 3-4 } \\
\text { orang. }\end{array}$ & 15 & 12,5 \\
\hline 3 & Jumlah siswa yang terlibat aktif dalam 5 - 6 orang. & 22 & 18,33 \\
\hline 4 & Ada pembagian tugas anggota kelompok & 24 & 20 \\
\hline 5 & Tidak ada pembagian tugas anggota dalam kelompok & 11 & 9,16 \\
\hline 6 & Tugas dilaksanakan sesuai dengan prosedur. & 38 & 31,66 \\
\hline 7 & $\begin{array}{l}\text { Tugas dilaksanakan tidak sesuai dengan langkah - } \\
\text { langkah. }\end{array}$ & 4 & 3,33 \\
\hline 8 & $\begin{array}{l}\text { Terdapat perilaku anggota kelompok yg tdk relevan } \\
\text { dengan KBM. }\end{array}$ & 0 & 0 \\
\hline
\end{tabular}

Keterangan : Jumlah $=$ jumlah total aktivitas dalam 1 siklus

$\%=$ persentase aktivitas

Mencermati tabel 4.4 aktivitas siswa dalam kelompok dengan menggunakan metode Goup Investigation dipaparkan pada uraian hasil penelitian berikut : Pada siklus II, aktivitas 3 yaitu kegiatan siswa dalam hal keterlibatannya secara aktif dalam kelompok, menunjukkan persentase yang meningkat yaitu 18,33\% yang berarti bahwa seluruh anggota terdiri dari enam orang siswa dalam satu kelompok, telah terlibat aktif dalam mengerjakan tugas yang diperintahkan guru. Sekitar $5 \%$ masih bertumpu pada 1 sampai 2 orang siswa saja dan 12,5 $\%$ bertumpu pada keterlibatan 3 sampai 4 orang saja. Aktivitas 4 dan 5 mengenai pembagian tugas anggota dalam kelompok pada siklus ini menunjukkan kenaikan yaitu 14,16\% pada siklus I menjadi $20 \%$ pada siklus II. Hal ini mengindikasikan bahwa tindakan guru dalam memotivasi siswa agar ada pembagian tugas yang jelas bagi anggota kelompok sudah dilaksanakan oleh para siswa. Pada aktivitas siswa berikutnya yaitu aktivitas 6 dan 7 mengenai kesesuaian pelaksanaan tugas dengan langkah-langkah / prosedur, menunjukkan persentase yang sangat meningkat dari 17,5\% menjadi 31,66 \%. Hal ini mengindikasikan bahwa setiap kelompok rata-rata telah menerapkan tugas sesuai dengan prosedur yang ditetapkan. Keadaan ini sangat berpengaruh pada kemampuan siswa secara individu dalam mengerjakan tugas. Dengan kemampuan yang dimiliki siswa dalam kelompoknya diharapkan secara individu juga mereka mampu melakukannya. Dengan demikian standar penilaian yang telah ditetapkan guru dalam KKM dapat tercapai sehingga siswa dapat 
Wahyuningsih S : Penerapan Model Pembelajaran Group Investigation Sebagai Upaya Meningkatkan Hasil Belajar Siswa Dalam Pembelajaran Agama Islam di Kelas IV SDN 064969 Kecamatan Medan Tembung Pada Semester 1 TP.2019/2020

dikatagorikan tuntas dalam kompetensi tersebut. Ketuntasan belajar ini dapat dipenuhi karena pada siklus II ini siswa tidak ada lagi yang melakukan tindakan yang tidak relevan dengan KBM. Persentase menunjukkan $0 \%$ siswa yang melakukan tindakan yang tidak relevan dengan KBM sangat jauh berbeda pada siklus I yang mencapai $15 \%$.

\section{Aktivitas Guru}

Selanjutnya mengenai hasil pengamatan aktivitas guru pada siklus II ini ditunjukkan pada tabel berikut:

Tabel 5 Aktivitas Guru Pada Siklus II

\begin{tabular}{|l|l|l|l|}
\hline & Katagori Pengamatan & \multicolumn{2}{l|}{ Siklus I } \\
\cline { 3 - 4 } No & & Jumlah & \% \\
\hline 1 & Menyampaikan Pendahuluan & 9 & 11,25 \\
\hline 2 & Menjelaskan materi / demonstrasi keterampilan & 4,5 & 5,62 \\
\hline 3 & Membagi kelompok siswa & 4,5 & 5,62 \\
\hline 4 & Membagikan tugas kepada kelompok & 2 & 2,5 \\
\hline 5 & Meminta siswa untuk mempersiapkan peralatan & 2,5 & 3,13 \\
\hline 6 & Memberikan instruksi dan motivasi & 2 & 2,5 \\
\hline 7 & Mengamati kegiatan siswa dalam kelompok & 28,5 & 35,63 \\
\hline 8 & Memberikan umpan balik terhadap keluhan siswa & 7 & 8,7 \\
\hline 9 & $\begin{array}{l}\text { Memberikan evaluasi singkat terhadap hasil kerja } \\
\text { kelompok }\end{array}$ & 10 & 12,5 \\
\hline 10 & Menutup pelajaran & 10 & 12,5 \\
\hline 11 & Perilaku yang tidak relevan & 0 & 0 \\
\hline
\end{tabular}

Keterangan : Jumlah $=$ jumlah total aktivitas dalam 1 siklus

$$
\%=\text { persentase aktivitas }
$$

Pada siklus II ini aktivitas yang dilakukan guru telah sesuai dengan rencana pembelajaran yang dibuat, dimana semua aktivitas pembelajaran telah dilakukan. Dari hasil pengamatan yang dilakukan oleh observer diperoleh hasil sebagaimana yang tertera pada tabel 4.5 di atas, bahwa aktivitas guru dalam menyampaikan pendahuluan lebih cepat dari waktu yang telah ditentukan yaitu 9 menit dengan persentase sebesar 11,25\%. Hal ini mengindikasikan bahwa guru telah melakukan kegiatan pendahuluan sesuai waktu yang ditentukan. Pada aktivitas ke-2 yaitu menjelaskan materi, guru melakukannya dengan waktu 4,5 menit atau 5,62 \%. Membagi kelompok membutuhkan waktu 4,5 menit atau 5,62 \%, membagikan tugas menyita waktu 2 menit atau 2,5\%, meminta siswa untuk mempersiapkan alat tulis 2,5 menit atau $3,13 \%$ dan memberikan instruksi menyita waktu 2 menit atau 2,5\%. Untuk aktivitas ke-7 yaitu mengamati kegiatan siswa dalam kelompok dan mengecek hasil kerja menggunakan waktu 28,5 menit atau 35,63 \%, memberikan umpan balik terhadap keluhan siswa membutuhkan waktu 7 menit atau 8,7 \%. Selanjutnya mengenai aktivitas ke-9 mengenai kegiatan evaluasi yang diberikan guru terhadap hasil kerja kelompok siswa membutuhkan waktu 10 menit atau 12,5\%. Dari pemaparan hasil pengamatan untuk aktivitas ke-2 sampai ke-9 seluruhnya membutuhkan waktu 60 menit, sesuai dengan RPP selama 60 menit. Hal ini mengindikasikan bahwa guru dalam melakukan kegiatan inti telah sesuai dengan waktu yang ditentukan. Pada aktivitas ke-10 yaitu kegiatan menutup pelajaran, guru menggunakan waktu selama 10 menit atau 12,5\%, sesuai dengan waktu yang ditetapkan yaitu selama 10 menit. Dari penjelasan hasil pengamatan observer ini menunjukkan bahwa sebenarnya guru telah melakukan kegiatan pembelajaran sesuai dengan RPP yang telah disusun. Apalagi dalam menyampaikan pelajaran, guru tidak ada melakukan aktivitas di luar kegiatan pembelajaran, dimana dari data observer menunjukkan bahwa aktivitas yang tidak relevan 
Wahyuningsih S : Penerapan Model Pembelajaran Group Investigation Sebagai Upaya Meningkatkan Hasil Belajar Siswa Dalam Pembelajaran Agama Islam di Kelas IV SDN 064969 Kecamatan Medan Tembung Pada Semester 1 TP.2019/2020

dengan $\mathrm{KBM}$ adalah $0 \%$. Ini mengindikasikan bahwa guru memang benar-benar menggunakan waktu dengan efektif.

\section{KESIMPULAN}

Berdasarkan temuan hasil penelitian tentang penerapan metode Group Investigation untuk meningkatkan hasil belajar siswa dalam pembelajaran Agama Islam Di Kelas IV SDN 064969 Kecamatan Medan Tembung Pada Semester 1 T.P.2019/2020 dapat ditarik kesimpulan sebagai berikut :

1. Penerapan Metode Group Investigation menunjukkan peningkatan hasil belajar siswa dalam Pembelajaran Agama Islam Di Kelas IV SDN 064969 Kecamatan Medan Tembung Pada Semester 1 T.P.2019/2020 hal ini terbukti dalam penelitian ini bahwa pada siklus II $86,67 \%$ dari siswa yang menjadi subjek penelitian tuntas belajar dengan nilai rata-rata 74,67.

2. Penerapan Metode Group Investigation menunjukkan peningkatan aktivitas belajar siswa dalam Pembelajaran Agama Islam Di Kelas IV SDN 064969 Kecamatan Medan Tembung Pada Semester 1 T.P.2019/2020 hal ini terbukti dalam penelitian ini bahwa siswa aktif belajar dalam kelompok, hal ini terbukti dari peningkatan hasil belajar kelompok dari rata-rata nilai 57 pada siklus I menjadi 87 pada siklus II.

\section{DAFTAR PUSTAKA}

Abdurrahman, Mulyono. 1999. Pendidikan Bagi Anak Berkesulitan Belajar. Jakarta: Rineka Cipta. Arsyad Azhar, Prof. Dr. M.A. 2004. Media Pembelajaran. Jakarta : P.T. Raya Grafindo Persada.

Arends, R. I. 1998. Classroom Instruction and Management. New York: McGraw-Hill. Copyright www.m-edukasi.web.id Media Pendidikan Indonesia

Arikunto,Sumarsimi. 1993 ”Dasar-dasar Evaluasi Pendidikan”. Jakarta: Bumi Aksara.

Branson. 1998. The Role of Civic Educatin. Calabassas: CCE.

Bloom, Benjamin S. 1982. Human Characteristics and School Learnin. New York: McGraw-Hill Book Company.

Dahar, R.W. 1991. "Teori-teori Belajar". Jakarta: Erlangga.

Dimyati, Mudjiono. 1999. Belajar dan Pembelajaran. Jakarta: Rineka Cipta.

Depdiknas. 2003. Kegiatan Belajar Mengajar yang Efektif. PUSKUR Depdiknas. Jakarta.

Gagne R.M. dan Brigss, L.J. 1975. Principle of Instructional Design. New York: Holt, Reinehart and Winston.

Harrow, Anita J. 1977. A taxonomy of The Psichomotor Domain. New York: david Mc Kay Company Inc.

Slavin. 1995. Cooperative Learning Theory, Research and Practice. Second Edition, Massachusetts: Ally and Bacon Publishers.

Sharan Y \& Sharan S. 1992. Expanding Coperative Learning Through Group Investigation. New York : Teachers Collage Press.

Undang-Undang Republik Indonesia No. 20 Tahun 2003 tentang Sistem Pendidikan Nasional (Sisdiknas). Jakarta : Sinar Grafika

\begin{tabular}{|l|l|l|l|}
\hline Accepted Date & Revised Date & Decided Date & Accepted to Publish \\
\hline 19 November 2020 & 23 November 2020 & 02 Desember 2020 & Ya \\
\hline
\end{tabular}

